\title{
Integrated Monitoring with Moss-Bag and Mussel Transplants in Reservoirs
}

\author{
Gana Gecheva ${ }^{1, *}$, Vesela Yancheva ${ }^{1}$, Iliana Velcheva ${ }^{1}$, Elenka Georgieva ${ }^{1}$, Stela Stoyanova ${ }^{1}$, \\ Desislava Arnaudova ${ }^{1}$, Violeta Stefanova ${ }^{2}{ }^{(0)}$, Deyana Georgieva ${ }^{2}{ }^{(1)}$, Vesela Genina ${ }^{3}$, \\ Borislava Todorova ${ }^{1}$ and Ivelin Mollov ${ }^{1}$ \\ 1 Faculty of Biology, Plovdiv University, 4000 Plovdiv, Bulgaria; veselayancheva@yahoo.com (V.Y.); \\ anivelcheva@abv.bg (I.V.); e_tomova@abv.bg (E.G.); stela.st@abv.bg (S.S.); desiarnaudova23@abv.bg (D.A.); \\ borislava_todorova@yahoo.co.uk (B.T.); mollov_i@uni-plovdiv.bg (I.M.) \\ 2 Faculty of Chemistry, Plovdiv University, 4000 Plovdiv, Bulgaria; stefanova@uni-plovdiv.net (V.S.); \\ georgieva@uni-plovdiv.bg (D.G.) \\ 3 Regional Laboratory, Executive Environmental Agency, Ministry of Environment and Water, 4000 Plovdiv, \\ Bulgaria; vgenina@abv.bg \\ * Correspondence: ggecheva@mail.bg; Tel.: +359-32-261-519
}

Received: 13 May 2020; Accepted: 22 June 2020; Published: 24 June 2020

\begin{abstract}
For the first time, transplants with moss-bags and mussels together were applied to study the water quality in standing water bodies. The tested species: Fontinalis antipyretica Hedw. and Sinanodonta woodiana (Lea, 1834) were collected from unpolluted sites and analyzed to obtain background levels. Then, the moss and mussels were left in cages for a period of 30 days in three reservoirs where both are not present naturally. Two of the reservoirs suffer from old industrial contamination and one is affected by untreated wastes. Twenty-four compounds were studied, among them trace elements $\mathrm{Al}, \mathrm{As}, \mathrm{Cd}, \mathrm{Co}, \mathrm{Cr}, \mathrm{Cu}, \mathrm{Fe}, \mathrm{Hg}, \mathrm{Mn}, \mathrm{Ni}, \mathrm{Pb}, \mathrm{Zn}$ and organic priority substances: six polybrominated diphenyl ethers (PBDEs) congeners and short-chain chlorinated paraffins (SCCPs). The trace element accumulation was significant after the exposition period in all studied stations. PBDEs and SCCPs were also accumulated up to two times more in the moss tissues. PBDEs in the mussels exceeded the environmental quality standard (EQS). The applied combined transplants, and especially the moss-bags, revealed severe contamination with heavy metals not detected by the water samples. The moss and the mussel followed a different model of trace element and PBDEs accumulation. The SCCPs levels were alarmingly high in all plant samples. The study confirmed PBDEs and SCCPs as bioaccumulative compounds and suggested that an EQS for SCCPs in biota needs to be established.
\end{abstract}

Keywords: moss-bags; mussels; trace elements; heavy metals; PBDEs; SCCPs

\section{Introduction}

Heavy metals are among the most common contaminants in the aquatic environment [1] and due to their excessive accumulation, biomagnification, and toxicity, high levels of heavy metals in surface waters have evoked significant concern from governments and the public [2]. Polybrominated diphenyl ethers (PBDEs) due to their persistence, bioaccumulation, long-range transport, toxicity, and adverse effects on wildlife and humans have been restricted or banned in most countries [3,4]. On the other hand, PBDEs are mainly used in plastic, textile, and electronic applications as fire retardants $[5,6]$. Short-chain chlorinated paraffins (SCCPs) are used for various industrial applications, such as flame retardants, plasticizers, metal-working fluids, lubricant additives, paints, sealants, and leather fat liquors. Due to their environmental persistence, potentials for bioaccumulation, and long-range 
atmospheric transport, in 2017, the Stockholm Convention listed SCCPs as a new group of persistent organic pollutants (POPs) [7,8]. Moreover, compared with medium-chain CPs (MCCPs, C14-17) and long-chain CPs (LCCPs, C18-30), short-chain CPs (SCCPs, C10-13) have higher toxicity effects on aquatic organisms, slower biodegradation rates, and, therefore, the most significant potential for long-range transport, persistence, and bioaccumulation $[9,10]$. There is very limited data on the environmental exposure of PBDEs and SCCPs in aquatic environments, especially on the potential accumulation in aquatic mosses and mussels. A review of PBDEs in the global environment recommended that more research needs to be performed on PBDEs in a variety of matrices and locations in order to assess the current status of these compounds [11]. SCCPs were found to be bioaccumulated by invertebrates and fish from Lake Ontario and Lake Michigan [12], and their possible biomagnification was also indicated [13].

Trace element and persistent organic pollution in aquatic ecosystems is traditionally monitored using chemical analyses of water and sediments [14,15]. Moreover, heavy metals and organic contaminants can bioaccumulate in aquatic organisms depending on their concentration in the waterfront, interaction with suspended organic matter, and bioavailability in sediments [16]. Therefore, biomonitoring can be used to determine the toxicant fraction in the environmental matrices (e.g., water and sediment) that is of ecotoxicological significance [17]. According to Azizi et al. [18], monitoring programs use a high number of bioindicators known as "sentinel organisms" to detect the temporal and spatial variation of contaminants and to contribute to the knowledge of trends in aquatic contamination.

The moss-bag technique was widely used to monitor air pollution. However, this simple and economical biomonitoring approach is rarely used to evaluate the aquatic environment quality, especially in lentic ecosystems. In comparison with the chemical monitoring of the pollutant concentrations in the water, the bryomonitoring technique allows the detection of intermittent or sporadic contamination, precise location of contamination sources, and simultaneous monitoring of a large number of contaminants (inorganic and organic) via analysis of a single sample [19]. Furthermore, active bryomonitoring can be used in environments where native mosses are absent, and it improves interpretation of the temporal variation in contaminants by taking into consideration the initial concentrations and time of exposure. The first transplants were applied fifty years ago [20]. Transplants of Fontinalis antipyretica Hedw. have been used to assess river pollution, mainly with heavy metals [21,22]. Fontinalis antipyretica is widespread throughout the northern hemisphere, and it is the most easily recognized aquatic species, as well as it is the most commonly used moss to monitor water quality [23].

Due to their sedentary filter-feeding, geographical distribution, size, and high contaminant bioconcentration facts, mussels are also widely used for assessing the ecological risk of different contaminants [24]. In fact, the Mussel Watch [25,26] is the oldest biomonitoring program in progress worldwide, and it has been successfully developed in many countries to determine the occurrence and the toxic effects of heavy metals in aquatic ecosystems and also human health [27-31]. The Chinese pond mussel, Sinanodonta woodiana (Bivalvia: Unionida: Unionidae) is a widely distributed benthic, freshwater species, with a native range that expands into East Asia from the Russian Far East (Amur Basin) to Taiwan, Indo-China, and Malaysia [32,33]. Currently, the species has widely spread across many regions, e.g., Europe, the USA, Hispaniola, Costa Rica, Indonesia, and the Philippines [34,35]. Moreover, according to Kolarević et al. [36], it fulfills the main criteria required for a bioindicator organism. Earlier studies have revealed the ability of Sinanodonta woodiana (S. woodiana) to accumulate trace elements [37] and pesticides [38], as well as its potential to detect genotoxicity [39], lysosomal membrane destabilization, and respiration rate [40,41]. Lastly, S. woodiana is a traditionally edible species in its native range, including China [42], and the monitoring of different toxicants is essential in terms of human health.

Although active biomonitoring has proven its effectiveness, until now, moss-bags were not applied in standing water bodies, except for a research in a Cu-contaminated lake in Italy [43]. Furthermore, 
to our knowledge, no studies on simultaneously transplanted mosses and mussels have been performed except a single study on trace metal contamination in rivers in France [44].

Therefore, in the present paper, we aimed to see whether contamination with trace elements and organic contaminants in reservoirs can be detected with the moss-bags technique and caged mussels. For this reason, alive individuals of Fontinalis antipyretica (F. antipyretica) and Sinanodonta woodiana from unpolluted sites were exposed during the summer of 2019 at three reservoirs influenced by industry and untreated wastes in order to study the contamination patterns in both, water and biota.

\section{Materials and Methods}

\subsection{Field Design}

Individuals of the aquatic moss F. antipyretica were collected from a small unpolluted stream $\left(42.119625^{\circ} \mathrm{N}, 24.556055^{\circ} \mathrm{E}\right.$ WGS 84) in Bulgaria. The material was rinsed on-site with the stream water before being transferred to the laboratory. Basal material, material in poor condition, and epiphytes and other foreign objects were removed. The material was divided into three parts for the three studied reservoirs. Flat bags $(30 \times 20 \mathrm{~cm})$ were prepared with plastic mesh (aperture $1 \mathrm{~mm})$, which was previously rinsed in distilled water and air-dried.

Mussels from one size class $(154 \pm 5.5 \mathrm{~g} ; 11 \pm 3.5 \mathrm{~cm})$ were collected manually from a pool of the Institute of Fisheries and Aquaculture (Bulgaria), where abiotic factors are monitored regularly, and there are no sources of anthropogenic contamination. The mussels were transported to the laboratory on the same day in clean plastic containers filled with pool water. They were left in an aquarium filled with dechlorinated water and pool water (50:50) and fitted with air pumps until the field experiment started. Biometric analyses were performed before and after the exposition according to Gasmi et al. [45]. The total weight (Ww, g) of each mussel was measured after cleaning the outer shells from particles with an analytical balance (Kern, Germany) in g. The shells were measured with a caliper in $\mathrm{mm}$.

Samples from both moss and mussels were taken for analyses of the 24 selected compounds ( $\mathrm{Al}$, As, Ca, Cd, Co, Cr, Cu, Fe, Hg, K, Mg, Mn, Na, Ni, P, Pb, Zn, PBDE 28, PBDE 47, PBDE 99, PBDE 100, PBDE 153, PBDE 154, SCCPs) in order to obtain background levels.

The moss-bags ( $100 \mathrm{~g}$ of F. antipyretica wet weight) together with the mussels $(\mathrm{n}=10)$ were placed in cages $(30 \times 15 \times 10 \mathrm{~cm}$; galvanized steel $)$ at a depth of $2 \mathrm{~m}$ in each of the reservoirs. The cages were removed from the reservoirs 30 days after the start of the experiment. Water samples from a depth of $2 \mathrm{~m}$ were taken simultaneously for inorganic and organic chemical analyses. The mussels' total soft tissues were dissected out for further chemical analyses according to the adapted for mussels EMERGE protocol (European Mountain lake Ecosystems: Regionalisation, diaGnostic and socioeconomic Evaluation) [46]. The exposure sites were located at three large, deep reservoirs (maximum depth between 48 and $98 \mathrm{~m}$ ) with different uses (energy and water supply, irrigation, fish farming) and affected by a different type of pollution (Figure 1). In such conditions, aquatic bryophytes are absent. Kardzhali $\left(41.638475^{\circ} \mathrm{N}\right.$, $25.304432^{\circ}$ E WGS 84) and Studen Kladenets $\left(41.631311^{\circ} \mathrm{N}, 25.519459^{\circ}\right.$ E WGS 84) reservoirs suffer from old industrial contamination, especially ore extraction and mining activities [47], and have sediment loads of priority substances. Zhrebchevo Reservoir $\left(42.585571^{\circ} \mathrm{N}, 25.885592^{\circ} \mathrm{E}\right.$ WGS 84$)$ is located in a region with light industries but is under the influence of illegal dumping sites (solid waste) and untreated wastewaters. Another reason for selection of the three heavily modified water bodies is that biomonitoring with $S$. woodiana in human-made lakes minimizes the potential threats caused by accidentally introduced species. As was mentioned above, all three studied reservoirs belong to the type large, deep reservoirs with concrete walls surrounding the prevailing part of their area. The only possible stations for positioning of the cages were shallow areas, which are used for fish farming. 


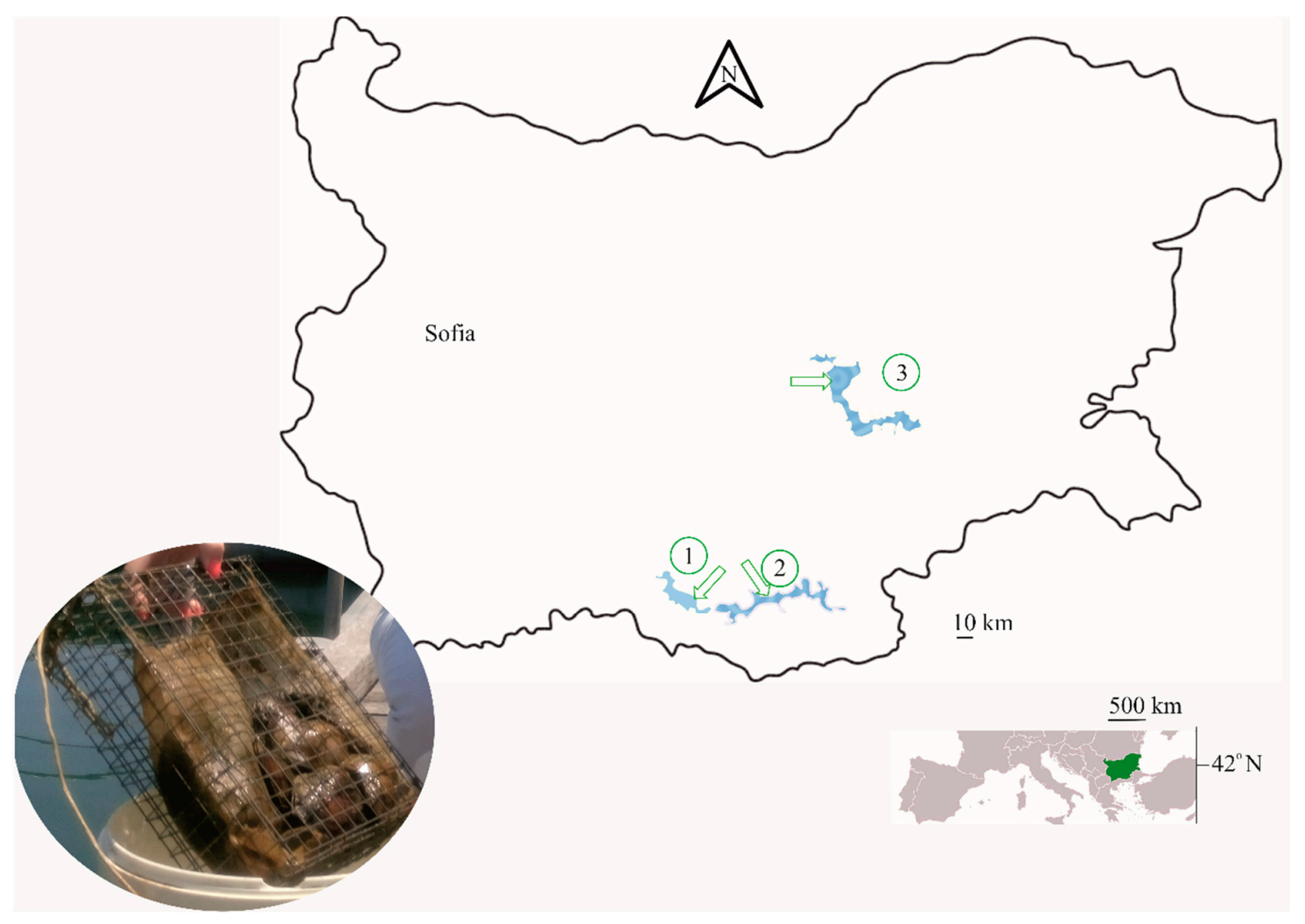

Figure 1. Studied standing water bodies: 1-Kardzhali; 2-Studen Kladenets; 3-Zhrebchevo Reservoir and location of the sampling sites (arrows).

\subsection{Analytical Procedures}

All samples were transported in coolers to the laboratories on the day of the sampling. The plant material was rinsed on-site with the reservoir water before being transferred to the laboratory, and material in poor condition and foreign objects were removed. Two to three-centimeter tips of F. antipyretica and whole-tissue samples from the mussels were analyzed. The moss samples were mineralized in a microwave digestion system (Ethos 1, Milestone, Denmark) following the procedure described in a previous work [48]. Briefly, the homogenized air-dried material $(\sim 1 \mathrm{~g})$ was treated with $8 \mathrm{~mL}$ of $\mathrm{HNO}_{3}\left(65 \%\right.$, Merck, Darmstadt, Germany supra pure) overnight, then $2 \mathrm{~mL}$ of $\mathrm{H}_{2} \mathrm{O}_{2}(30 \%$, Merck, Darmstadt, Germany, pa) were added, containers were sealed and irradiated. Fresh frozen mussel samples were homogenized by grinding, and $\sim 2 \mathrm{~g}$ of the material was directly subjected to MB dissolution with the same mixture of $\mathrm{HNO}_{3}$ and $\mathrm{H}_{2} \mathrm{O}_{2}$ (8:2). After digestion, the samples were transferred in volumetric flasks $(50 \mathrm{~mL}$ ) and diluted with double distilled water (Fison Scientific Equipment, Fi-stream). For determination of trace elements, the sample solutions were measured directly, while for the elements with higher concentrations, such as $\mathrm{Al}, \mathrm{Ca}, \mathrm{Fe}, \mathrm{K}, \mathrm{Mg}, \mathrm{Mn}, \mathrm{Na}$, and $\mathrm{P}$, the sample solutions were additionally diluted by a factor of 5 . The water samples were stabilized in $0.5 \% \mathrm{HNO}_{3}$. Blank samples were prepared for each batch of samples. The elements $\mathrm{Na}(589.592 \mathrm{~nm})$; $\mathrm{K}(766.490 \mathrm{~nm}) ; \mathrm{Mg}(285.213 \mathrm{~nm}) ; \mathrm{Ca}(422.673 \mathrm{~nm})$, and Fe $(238.204 \mathrm{~nm})$ were determined by ICP-AES using iCAP 6300 Duo, S (Thermo Scientific, Waltham, MA, USA) using radial observation mode.

The elements and corresponding monitored isotopes $31 \mathrm{P} ; 52,53 \mathrm{Cr} ; 59 \mathrm{Co} ; 60,62 \mathrm{Ni} ; 63,65 \mathrm{Cu}$; 64, 66 Zn; 75 As; 111,113 Cd; 206, 208 Pb; and 201, 202 Hg were determined by ICP-MS (Agilent 7700, Agilent Technologies, Tokyo, Japan). Two isotopes per element (where possible) were monitored for dynamic evaluation of potential spectral matrix interference, and $\mathrm{He}(4.8 \mathrm{~mL} / \mathrm{min})$ was used as collision gas in order to prevent polyatomic ion formation. Additionally, two tungsten isotopes $(182,184 \mathrm{~W})$ were permanently monitored in order to ensure dynamic assessment of the risk of overlapping the 
mercury signals by tungsten oxide radicals. In order to assure quantification of very low concentration of $\mathrm{Hg}$ in the tested samples, the observation time for both isotopes was increased up to $0.5 \mathrm{~s}$.

The elements $\mathrm{Al}$ and $\mathrm{Mn}$ were measured by both methods (ICP-AES and ICP-MS) at the corresponding emission lines (Mn 259.373 $\mathrm{nm}$ and $\mathrm{Al} 396.152 \mathrm{~nm}$ ) and isotopes (27 $\mathrm{Al}$ and $55 \mathrm{Mn}$ ).

The non-spectral matrix effect and sensitivity drift inherent for the ICP-MS method were corrected by internal standardization. For this purpose, $103 \mathrm{Rh}$ was selected as the most appropriate internal standard and was introduced to the calibration solutions as well as to the measured samples.

For calibration, the following traceable to NIST standard solutions were used after appropriate dilution: ICP multi-element standard solution IV, Certipur (Merck, Darmstadt, Germany); single-element standard solutions for $\mathrm{K}, \mathrm{Na}, \mathrm{P}, \mathrm{As}, \mathrm{Hg}$, and $\mathrm{Rh}$ (CPAChem, Stara Zagora, Bulgaria-France).

For validation of the developed analytical methods, a certified reference material NCS DC 73,348- "Bush Branches and Leaves" was applied, and the obtained recoveries for all tested elements varied between $93.8 \%$ for $\mathrm{Cr}$ and $109 \%$ for $\mathrm{Al}$.

The limits of detection (LOD) for $\mathrm{Al}$ and $\mathrm{Hg}$ were $<0.005$, for $\mathrm{As}<1$, for $\mathrm{Cd}$ and $\mathrm{Fe}<0.1$ and for $\mathrm{Co}<0.01 \mathrm{mg} \mathrm{L}^{-1}$ in water. The concentrations in water and biota were presented in $\%, \mu \mathrm{g} \mathrm{L}^{-1}$, and $\mathrm{mg} \mathrm{L}^{-1}$ for water samples and in $\mathrm{mg} \mathrm{kg}^{-1}$ for biota, respectively. Six PBDE congeners (BDEs 28, 47, 99, 100, 153, and 154) and SCCPs were analyzed in the extracted matrices (water and biota) by gas chromatography-mass spectrometry (GC-MS) with electron capture negative ionization (Thermo TSQ 8000 triple quadrupole, Thermo Scientific, Waltham, MA, USA) according the following standard methods: EN 16,694-2015 and ISO 12010:2019. The capillary column $(20 \mathrm{~m} \times 0.18 \mathrm{~mm} \times 0.18 \mu \mathrm{m}$, Restek) was used.

Before the analysis of PBDEs and SCCPs in water, $0.1 \mu \mathrm{g} \mathrm{mL}^{-1}$ deuterated standard was added to the samples, and solid-phase extraction was applied. The extracts were concentrated with a rotary vacuum evaporator to $1 \mathrm{~mL}$. The injection volume was $1 \mu \mathrm{L}$, and the injection was performed in the splitless mode. For PBDEs, helium was employed as carrier gas $\left(0.9 \mathrm{~mL} \mathrm{~min}^{-1}\right)$, and $\mathrm{Ar}$ was used as the collision gas. The GC oven temperature was programmed at $80^{\circ} \mathrm{C}(1 \mathrm{~min})$, from 20 to $140{ }^{\circ} \mathrm{C}$ (0 min), and from 8 to $310^{\circ} \mathrm{C}$ (5 min); while for the determination of SCCPs, methane was used as carrier gas $\left(1.3 \mathrm{~mL} \mathrm{~min}^{-1}\right)$ at the following temperature program: $100{ }^{\circ} \mathrm{C}(0.5 \mathrm{~min})$, from 10 to $150{ }^{\circ} \mathrm{C}$ (0.5 min), and from 30 to $280^{\circ} \mathrm{C}(7 \mathrm{~min})$.

The sample preparation of biota samples (moss and mussels) involved a grinding step followed by extraction with ethyl acetate. The extract was concentrated and purified by adsorption chromatography, resulting in PBDEs being separated from the chlorinated compounds. The PBDE-containing fraction was concentrated and subjected to GC-MS analysis at the same conditions as mentioned above.

The quality control for PBDE determination was assured with the following reference materials: 2,4,4'-triBDE/PBDE 28; 2,2',4,4'-tetraBDE/PBDE 47; 2,2',4,4',5-pentaBDE/PBDE 99;

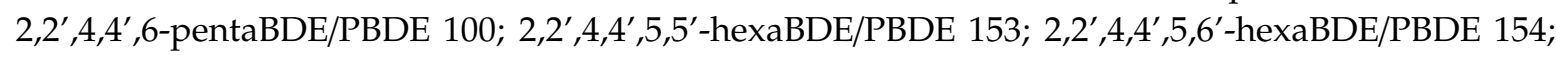
3,3',4,4'-tetraBDE/BDE-77-CS; chloroparaffin C10-C13 51.5\% Cl (Dr. Ehrenstorfer G173357CY); chloroparaffin C10-C13 63\% Cl (Dr. Ehrenstorfer G737766CY) chloroparaffin C10-C15, 55.5\% Cl (Dr. Ehrenstorfer G G162881CY), and alpha HCH D13 (Dr. Ehrenstorfer).

The analyzed sum of SCCPs includes the variety of SCCPs with their differing chlorine content and C-number distribution patterns following ISO 12010:2019.

The method was validated by two certified reference materials: NIST SRM-1974c "Organics in Mussel Tissue (Mytilus edulis)" (Sigma Aldrich, St. Louis, MO, USA) and LGC reference material R 542, EDF 2524 "Clean fish" (UK).

The LOD for the PBDE congeners were 0.004 in water and $0.003 \mu \mathrm{g} \mathrm{L}^{-1}$ in biota; and for SCCPs 0.15 in water and $1.5 \mu \mathrm{g} \mathrm{L}^{-1}$ in biota. The concentrations in water and biota were presented in $\mu \mathrm{g} \mathrm{L}^{-1}$ and $\mu \mathrm{g} \mathrm{kg}^{-1}$, respectively. 


\subsection{Contamination Factors and Metal Pollution Index}

Metal enrichment in moss tissues was established based on contamination factor (CF), calculated as the ratio between the metal content at a given reservoir and the unpolluted stream. The following scale based on the geometric progression adopted by Mouvet [49] was applied:

- $\quad \mathrm{CF}<2$, normal condition (blue)

- $2 \leq \mathrm{CF}<6$, suspected pollution (green)

- $6 \leq \mathrm{CF}<18$, certain pollution (yellow)

- $18 \leq \mathrm{CF}<54$, strong pollution (orange)

- $54 \leq \mathrm{CF}$, extreme pollution (red).

The threshold discriminating between suspected and certain pollution $(\mathrm{CF}=6)$ is high enough to minimize the effects of possible variability sources (e.g., interspecific differences in cation exchange capacity, intraspecific differences due to the vertical position in the water column or to the horizontal position in the streambed, seasonal changes, water chemistry, sample treatment, analytical errors).

An evaluation of the overall metal contamination in moss samples was carried out by calculating a metal pollution index (MPI) derived as a linear sum of the contamination factors weighted to take into account the differences in toxicity of the various metals [50], i.e.,

$$
\mathrm{MPI}=\Sigma \mathrm{i}(w \mathrm{i} / \mathrm{wt}) \times \mathrm{CFi}
$$

where $\mathrm{CFi}$ is the contamination factor for metal $\mathrm{i}$; wi is the weight for metal $\mathrm{i}$; and $w t=\Sigma i w i$.

The weights ( $\mathrm{Zn}, 1 ; \mathrm{Cu}, 5 ; \mathrm{Cr}, \mathrm{Pb}$, and $\mathrm{Ni}, 100 ; \mathrm{Cd}, 500)$ were established as previously reported by Gonçalves et al. [50] and applied by Soares et al. [51]. The following classification scale after Soares et al. [51] was adapted for the purposes of this study and reflected five classes (and colors) relevant for the Water Framework Directive 2000/60/EC [52]:

MPI $\leq 1$-unpolluted by 6 metals (blue);

$1 \leq \mathrm{MPI} \leq 2.1$-low contamination (green);

$2.1 \leq \mathrm{MPI} \leq 4.5$-moderate contamination (yellow);

$4.5 \leq \mathrm{MPI} \leq 6.5$ - strong contamination (orange);

MPI $\geq 6.5$ - heavy contamination (red).

The bioaccumulation factor (BAF) for trace elements and organic contaminants for the mussels was calculated after Nikanorov [53] according to the formula shown below:

$\mathrm{BAF}=$ (toxicant concentration in mussel total soft tissue)/(toxicant concentrations in water).

In general, the BAF calculations show how many times more the concentration of the toxicant in biota is compared to that in the water. According to its values, the biota could be categorized as macro $(\mathrm{BAF}>2)$, micro $(\mathrm{BAF}=1$ to 2$)$, and deconcentrators $(\mathrm{BAF}<1)$. 


\subsection{Statistical Analysis}

The similarity of the accumulated pollutants in the aquatic moss and mussels was assessed using cluster analysis (unweighted pair-group average, Bray-Curtis similarity index). All statistical tests were performed using the computer software "PAST" [54]. A level of probability p $\leq 0.05$ was accepted as statistically significant. The relationship between the analyzed toxicants in water, moss, and mussel samples was studied with principal component analysis (PCA). The data were transformed $\left(x^{\prime}=\log (x+1)\right)$, automatically centered, and standardized by the Canoco v.5 program [55].

\section{Results and Discussion}

\subsection{Water}

The water in all the reservoirs was alkaline, with $\mathrm{pH}$ values between 6.84 and 8.29. The concentrations in water samples were below the LOD for $\mathrm{Hg}\left(<0.05 \mu \mathrm{g} \mathrm{L}{ }^{-1}\right)$ and Fe $\left(<0.1 \mathrm{mg} \mathrm{L}^{-1}\right)$ at all sampling locations (Table 1). All the remaining 14 analyzed elements had minimum levels at the background station, except for $\mathrm{Mg}$, which had its minimum in the Kardzhali Reservoir. Most of the analyzed elements had maximum concentrations in the water from Studen Kladenets Reservoir (As, Cd, Co, Cu, Mn, Ni, P, Pb, Zn). Aluminum and $\mathrm{Cr}$ had maximums in Kardzhali, while $\mathrm{Na}$ and $\mathrm{Mg}$ had maximums in the Zhrebchevo Reservoir. The analyzed $\mathrm{Cd}, \mathrm{Pb}, \mathrm{Ni}$, and $\mathrm{Hg}$ values did not exceed the allowable concentrations set in the EQS according to Directive 2008/105/EC, updated in 2013 (2013/39/EU).

All studied PBDE congeners and SCCPs were below the LOD in water samples from the background stations, except for BDE-99 and 100 (Table 1). The maximums were analyzed in waters from Kardzhali and Studen Kladenets reservoirs. BDE-47 and -153 were the dominant congeners determined in all water samples. Total PBDEs in water samples did not exceed the EQS, while SCCPs were above the EQS in Zhrebchevo Reservoir (about three times greater). The later confirmed the impact of untreated wastes discharged directly into the reservoir and along the banks. 
Table 1. Analyzed concentrations in water, moss, and mussel samples. For stations, please refer Figure 1; n.a.- not analyzed.

\begin{tabular}{|c|c|c|c|c|c|c|c|c|c|c|c|c|c|c|c|}
\hline & \multicolumn{5}{|c|}{ Water } & \multicolumn{6}{|c|}{ Moss } & \multicolumn{4}{|c|}{ Mussels } \\
\hline & & Background & 1 & 2 & 3 & & Background & 1 & 2 & 3 & & Background & 1 & 2 & 3 \\
\hline \multirow{2}{*}{$\mathrm{Al}$} & $\mathrm{mg} \mathrm{L}^{-1}$ & $<0.005$ & 0.11 & 0.03 & 0.05 & $\%$ & 0.16 & 1.45 & 1.34 & 1.33 & $\mathrm{mg} \mathrm{kg}^{-1}$ & 14.4 & 36.6 & 35.7 & 36.9 \\
\hline & RSD\% & - & 7.6 & 13.3 & 11.4 & RSD\% & 8.9 & 5.6 & 6.7 & 5.0 & RSD\% & 11.1 & 6.2 & 5.7 & 6.9 \\
\hline \multirow{2}{*}{ As } & $\mu \mathrm{g} \mathrm{L}^{-1}$ & $<1$ & 1.2 & 5.2 & $<1$ & $\mathrm{mg} \mathrm{kg}^{-1}$ & 1.3 & 8.0 & 5.3 & 4.3 & $\mathrm{mg} \mathrm{kg}^{-1}$ & 0.37 & 0.80 & 0.63 & 1.15 \\
\hline & RSD \% & - & 9.4 & 4.9 & - & RSD \% & 5.2 & 6.8 & 8.1 & 15 & RSD\% & 6.4 & 7.5 & 9.3 & 8.8 \\
\hline \multirow[b]{2}{*}{$\mathrm{Ca}$} & & \multirow{2}{*}{\multicolumn{4}{|c|}{ n.a. }} & $\%$ & 0.75 & 1.4 & 1.8 & 4.3 & $\%$ & 0.89 & 1.4 & 1.9 & 2.0 \\
\hline & & & & & & RSD\% & 2.9 & 2.9 & 1.9 & 1.0 & RSD\% & 3.1 & 2.1 & 2.4 & 2.3 \\
\hline \multirow{2}{*}{$\mathrm{Cd}$} & $\mu \mathrm{g} \mathrm{L}^{-1}$ & $<0.1$ & $<0.1$ & 0.32 & $<0.1$ & $\mathrm{mg} \mathrm{kg}^{-1}$ & 0.07 & 0.53 & 9.1 & 0.31 & $\mathrm{mg} \mathrm{kg}^{-1}$ & 0.09 & 0.17 & 0.38 & 0.19 \\
\hline & RSD\% & - & - & 7.9 & - & RSD\% & 21 & 15.6 & 4.8 & 14.9 & RSD\% & 10 & 6.0 & 5.6 & 13 \\
\hline \multirow{2}{*}{ Co } & $\mu \mathrm{g} \mathrm{L}^{-1}$ & $<0.01$ & $<0.01$ & 0.26 & $<0.01$ & $\mathrm{mg} \mathrm{kg}^{-1}$ & 1.6 & 7.1 & 8.0 & 4.8 & $\mathrm{mg} \mathrm{kg}^{-1}$ & 0.14 & 0.20 & 0.21 & 0.27 \\
\hline & RSD\% & - & - & 5.4 & - & RSD\% & 3.1 & 2.1 & 3.6 & 5.3 & RSD \% & 6.0 & 7.1 & 5.8 & 7.4 \\
\hline \multirow{2}{*}{$\mathrm{Cr}$} & $\mu \mathrm{g} \mathrm{L}^{-1}$ & 0.06 & 0.18 & 0.06 & 0.13 & $\mathrm{mg} \mathrm{kg}^{-1}$ & 3.9 & 66 & 25 & 21 & $\mathrm{mg} \mathrm{kg}^{-1}$ & 0.15 & 0.22 & 0.14 & 0.19 \\
\hline & RSD $\%$ & 7.1 & 4.1 & 6.9 & 4.2 & RSD\% & 2.5 & 6.7 & 9.7 & 5.3 & RSD \% & 3.4 & 3.2 & 11.3 & 8.6 \\
\hline \multirow{2}{*}{$\mathrm{Cu}$} & $\mu \mathrm{g} \mathrm{L}^{-1}$ & 0.1 & 1.7 & 1.8 & 0.3 & $\mathrm{mg} \mathrm{kg}^{-1}$ & 10 & 34 & 282 & 53 & $\mathrm{mg} \mathrm{kg}^{-1}$ & 5.320 & 63 & 31.4 & 25.4 \\
\hline & RSD\% & 8.9 & 6.2 & 5.7 & 7.3 & RSD \% & 4.5 & 6.8 & 3.7 & 2.1 & RSD \% & 4.9 & 3.4 & 3.9 & 4.3 \\
\hline \multirow{2}{*}{$\mathrm{Fe}$} & $\mu \mathrm{g} \mathrm{L}^{-1}$ & $<0.1$ & $<0.1$ & $<0.1$ & $<0.1$ & $\%$ & 0.23 & 1.2 & 1.2 & 1.2 & $\mathrm{mg} \mathrm{kg}^{-1}$ & 170 & 212 & 196 & 294 \\
\hline & RSD\% & - & - & - & - & RSD\% & 3.1 & 3.2 & 2.3 & 2.5 & RSD\% & 6.4 & 3.4 & 5.0 & 3.4 \\
\hline \multirow{2}{*}{$\mathrm{Hg}$} & $\mu \mathrm{g} \mathrm{L}^{-1}$ & $<0.05$ & $<0.05$ & $<0.05$ & $<0.05$ & $\mathrm{mg} \mathrm{kg}^{-1}$ & 0.02 & 0.03 & 0.05 & 0.06 & $\mathrm{mg} \mathrm{kg}^{-1}$ & 0.004 & 0.007 & 0.009 & 0.009 \\
\hline & RSD\% & - & - & - & - & RSD\% & 11.0 & 6.4 & 5.7 & 8.3 & RSD\% & 16 & 12 & 11 & 12 \\
\hline \multirow{2}{*}{ K } & & \multirow{2}{*}{\multicolumn{4}{|c|}{ n.a. }} & $\%$ & 1.01 & 0.22 & 0.57 & 0.65 & $\mathrm{mg} \mathrm{kg}^{-1}$ & 211 & 229 & 234 & 201 \\
\hline & & & & & & RSD\% & 2.4 & 2.2 & 2.8 & 3.8 & RSD \% & 4.2 & 4.0 & 5.5 & 4.7 \\
\hline \multirow{2}{*}{$\mathrm{Mg}$} & $\mathrm{mg} \mathrm{L}^{-1}$ & 3.4 & 2.6 & 3.6 & 12.1 & $\%$ & 0.20 & 0.60 & 0.42 & 0.52 & $\mathrm{mg} \mathrm{kg}^{-1}$ & 268 & 454 & 450 & 659 \\
\hline & RSD $\%$ & 5.0 & 5.9 & 6.4 & 2.6 & RSD \% & 1.9 & 2.1 & 2.6 & 1.8 & RSD \% & 3.8 & 2.8 & 3.1 & 2.6 \\
\hline
\end{tabular}


Table 1. Cont.

\begin{tabular}{|c|c|c|c|c|c|c|c|c|c|c|c|c|c|c|c|}
\hline & \multicolumn{5}{|c|}{ Water } & \multicolumn{6}{|c|}{ Moss } & \multicolumn{4}{|c|}{ Mussels } \\
\hline & & Background & 1 & 2 & 3 & & Background & 1 & 2 & 3 & & Background & 1 & 2 & 3 \\
\hline \multirow{2}{*}{ Mn } & $\mathrm{mg} \mathrm{L}^{-1}$ & 0.002 & 0.008 & 0.04 & 0.005 & $\mathrm{mg} \mathrm{kg}^{-1}$ & 1000 & 204 & 1948 & 338 & $\%$ & 0.134 & 0.188 & 0.198 & 0.254 \\
\hline & RSD \% & 6.8 & 5.2 & 3.3 & 5.3 & RSD\% & 6.0 & 8.2 & 3.3 & 5.1 & RSD\% & 7.5 & 5.0 & 5.6 & 4.0 \\
\hline \multirow{2}{*}{$\mathrm{Na}$} & $\mathrm{mg} \mathrm{L}^{-1}$ & 4.7 & 4.8 & 7.6 & 11.1 & $\mathrm{mg} \mathrm{kg}^{-1}$ & 273 & 140 & 147 & 306 & $\mathrm{mg} \mathrm{kg}^{-1}$ & 331 & 780 & 436 & 514 \\
\hline & RSD \% & 3.9 & 3.6 & 2.1 & 2.7 & RSD\% & 3.1 & 4.9 & 3.9 & 7.6 & RSD\% & 3.6 & 3.0 & 3.1 & 3.0 \\
\hline \multirow{2}{*}{$\mathrm{Ni}$} & $\mu \mathrm{g} \mathrm{L}^{-1}$ & 0.1 & 0.4 & 0.6 & 0.4 & $\mathrm{mg} \mathrm{kg}^{-1}$ & 3.7 & 74 & 21 & 17 & $\mathrm{mg} \mathrm{kg}^{-1}$ & 0.14 & 0.37 & 0.17 & 0.17 \\
\hline & RSD \% & 6.3 & 7.5 & 3.4 & 2.5 & RSD\% & 6.5 & 2.6 & 4.7 & 2.3 & RSD\% & 5.0 & 6.5 & 6.3 & 9.1 \\
\hline \multirow{2}{*}{$\mathrm{P}$} & $\mathrm{mg} \mathrm{L}^{-1}$ & $<0.01$ & 0.03 & 0.04 & $<0.01$ & $\%$ & 0.34 & 0.14 & 0.30 & 0.32 & $\mathrm{mg} \mathrm{kg}^{-1}$ & 0.43 & 0.93 & 1.07 & 1.20 \\
\hline & RSD \% & - & 9.2 & 8.2 & - & RSD $\%$ & 4.2 & 4.8 & 4.5 & 4.0 & RSD\% & 6.4 & 6.0 & 5.1 & 5.7 \\
\hline \multirow{2}{*}{$\mathrm{Pb}$} & $\mu \mathrm{g} \mathrm{L}^{-1}$ & 0.1 & 0.6 & 18 & 0.3 & $\mathrm{mg} \mathrm{kg}^{-1}$ & 4.4 & 37.0 & 383 & 18.9 & $\mathrm{mg} \mathrm{kg}^{-1}$ & 1.6 & 1.7 & 4.0 & 1.9 \\
\hline & RSD $\%$ & 5.9 & 5.0 & 4.6 & 5.9 & RSD\% & 6.0 & 6.7 & 4.7 & 2.1 & RSD\% & 6.8 & 5.7 & 7.9 & 3.6 \\
\hline \multirow{2}{*}{$\mathrm{Zn}$} & $\mu \mathrm{g} \mathrm{L}^{-1}$ & $<1$ & $<1$ & 20 & $<1$ & $\mathrm{mg} \mathrm{kg}^{-1}$ & 32 & 62 & 142 & 52 & $\mathrm{mg} \mathrm{kg}^{-1}$ & 55.1 & 11.5 & 32.6 & 15.7 \\
\hline & RSD $\%$ & - & - & 4.8 & - & RSD\% & 4.8 & 5.0 & 2.3 & 9.0 & RSD\% & 6.2 & 3.6 & 4.7 & 3.8 \\
\hline \multirow{2}{*}{ BDE 28} & $\mu \mathrm{g} \mathrm{L}^{-1}$ & $<0.004$ & 0.023 & 0.032 & $<0.004$ & $\mu \mathrm{g} \mathrm{kg}^{-1}$ & 0.005 & $<0.003$ & $<0.003$ & 0.042 & $\mu \mathrm{g} \mathrm{kg}^{-1}$ & 0.005 & $<0.003$ & 0.005 & $<0.003$ \\
\hline & \pm & & 0.006 & 0.009 & & \pm & 0.000 & & & 0.000 & \pm & 0.000 & & 0.000 & \\
\hline \multirow[t]{2}{*}{ BDE 47} & $\mu \mathrm{g} \mathrm{L}^{-1}$ & 0.005 & 0.012 & 0.005 & 0.005 & $\mu \mathrm{g} \mathrm{kg}^{-1}$ & 0.008 & 0.005 & 0.019 & $<0.003$ & $\mu \mathrm{g} \mathrm{kg}^{-1}$ & 0.005 & 0.005 & 0.005 & 0.005 \\
\hline & \pm & 0.000 & 0.000 & 0.000 & 0.000 & \pm & 0.000 & 0.000 & 0.000 & & \pm & 0.000 & 0.000 & 0.000 & 0.000 \\
\hline \multirow[t]{2}{*}{ BDE 99} & $\mu \mathrm{g} \mathrm{L}^{-1}$ & 0.012 & 0.017 & 0.018 & $<0.004$ & $\mu \mathrm{g} \mathrm{kg}^{-1}$ & $<0.003$ & 0.022 & 0.038 & 0.013 & $\mu \mathrm{g} \mathrm{kg}^{-1}$ & 0.013 & 0.015 & 0.010 & $<0.003$ \\
\hline & \pm & 0.000 & 0.000 & 0.000 & & \pm & & 0.000 & 0.000 & 0.000 & \pm & 0.000 & 0.000 & 0.000 & \\
\hline \multirow[t]{2}{*}{ BDE 100} & $\mu \mathrm{g} \mathrm{L}^{-1}$ & 0.009 & $<0.004$ & $<0.004$ & $<0.004$ & $\mu \mathrm{g} \mathrm{kg}^{-1}$ & 0.011 & 0.048 & 0.011 & $<0.003$ & $\mu \mathrm{g} \mathrm{kg}^{-1}$ & 0.007 & $<0.003$ & $<0.003$ & $<0.003$ \\
\hline & \pm & 0.000 & & & & \pm & 0.000 & 0.000 & 0.000 & & \pm & 0.000 & & & \\
\hline \multirow[t]{2}{*}{ BDE 153} & $\mu \mathrm{g} \mathrm{L}^{-1}$ & 0.014 & 0.012 & 0.018 & 0.014 & $\mu \mathrm{g} \mathrm{kg}^{-1}$ & 0.030 & $<0.003$ & 0.017 & 0.046 & $\mu \mathrm{g} \mathrm{kg}^{-1}$ & 0.014 & 0.016 & 0.014 & $<0.003$ \\
\hline & \pm & 0.000 & 0.000 & 0.000 & 0.000 & \pm & 0.000 & & 0.000 & 0.000 & \pm & 0.000 & 0.000 & 0.000 & \\
\hline \multirow[t]{2}{*}{ BDE 154} & $\mu \mathrm{g} \mathrm{L}^{-1}$ & $<0.004$ & 0.010 & $<0.004$ & $<0.004$ & $\mu \mathrm{g} \mathrm{kg}^{-1}$ & 0.010 & 0.013 & 0.014 & 0.014 & $\mu \mathrm{g} \mathrm{kg}^{-1}$ & $<0.003$ & $<0.003$ & 0.010 & $<0.003$ \\
\hline & \pm & & 0.000 & & & \pm & 0.000 & 0.000 & 0.000 & 0.000 & \pm & & & 0.000 & \\
\hline \multirow[t]{2}{*}{ SCCPs } & $\mu \mathrm{g} \mathrm{L}^{-1}$ & 0.58 & 0.86 & 1.2 & 3.9 & $\mu \mathrm{g} \mathrm{kg}^{-1}$ & 4.6 & 5.4 & 6.0 & 9.2 & $\mu \mathrm{g} \mathrm{kg}^{-1}$ & 7.4 & 0.56 & 6.1 & 0.22 \\
\hline & \pm & 0.12 & 0.17 & 0.24 & 0.8 & \pm & 1.4 & 1.6 & 1.8 & 2.7 & \pm & 2.2 & 0.17 & 1.8 & 0.07 \\
\hline
\end{tabular}




\subsection{Moss-Bags}

In this study, $\mathrm{Cd}, \mathrm{Cr}, \mathrm{Cu}, \mathrm{Ni}$, and $\mathrm{Pb}$ were accumulated by the moss between 17 and 130 times more than their respective background levels (Table 1). Significant contaminants analyzed in moss tissues were $\mathrm{Al}, \mathrm{As}, \mathrm{Cd}, \mathrm{Cr}, \mathrm{Cu}, \mathrm{Ni}$, and $\mathrm{Pb}$ (Table 2). The calculated $\mathrm{CFs}$ indicated certain pollution for $\mathrm{As}, \mathrm{Al}, \mathrm{Cr}$; strong for $\mathrm{Cu}$ and $\mathrm{Ni}$; and certain to extreme for $\mathrm{Cd}$ and $\mathrm{Pb}$. As a consequence, the MPIs derived revealed heavy contamination in both Kardzhali and Studen Kladenets reservoirs, which could be related to the former activity of metallurgical plant and industrial impact.

Table 2. Contamination factors for 11 elements in moss-bags, and metal pollution index (MPI) at the studied stations. Legend: yellow: certain/moderate pollution; orange: strong pollution; red: extreme/heavy pollution (following ranges of contamination factors and metal pollution index as in Material and Methods).

\begin{tabular}{cccc}
\hline Station & Kardzhali & Studen Kladenets & Zhrebchevo \\
\hline $\mathrm{Al}$ & 8.8 & 8.1 & 8.1 \\
$\mathrm{As}$ & 6.2 & 4.1 & 3.4 \\
$\mathrm{Cd}$ & 7.3 & 126 & 4.2 \\
$\mathrm{Co}$ & 4.5 & 5.1 & 3.1 \\
$\mathrm{Cr}$ & 17 & 6.4 & 5.4 \\
$\mathrm{Cu}$ & 3.3 & 28 & 5.2 \\
$\mathrm{Fe}$ & 5.5 & 5.5 & 5.2 \\
$\mathrm{Mn}$ & 0.2 & 1.9 & 0.3 \\
$\mathrm{Ni}$ & 20 & 5.8 & 4.5 \\
$\mathrm{~Pb}$ & 8.4 & 87 & 4.3 \\
$\mathrm{Zn}$ & 1.9 & 4.4 & 1.6 \\
$\mathrm{MPI}$ & 10 & 90 & 4.4 \\
\hline
\end{tabular}

The $\mathrm{Cu}$ and $\mathrm{Pb}$ concentrations measured in the moss-bags in the present study were similar to those reported for river transplants in areas contaminated due to past mining industries [56]. The comparison with transplanted F. antipyretica for 28 days in copper-contaminated Orta Lake in Italy [43] showed similar accumulation for $\mathrm{Cr}$ and $\mathrm{Pb}$; however, we determined higher values in the present study for $\mathrm{Cr}$ and lower ones for $\mathrm{Cu}$, respectively. The analyzed $\mathrm{Pb}$ concentrations in the transplants corresponded to the ambient water levels and confirmed that the accumulation of the elements with no metabolic function, increased with increasing the metal supply in the environment [57].

The transplanted moss $\mathrm{CFs}$ for $\mathrm{Cd}, \mathrm{Cu}$, and $\mathrm{Pb}$ were several times higher than $\mathrm{CFs}$ from a study of trace metals from past mining activities with F. antipyretica transplants in rivers in France [58]. Furthermore, the highest $\mathrm{CFs}$ in the present study were more than 30 times higher for $\mathrm{Cd}, 20$ times for $\mathrm{Cu}$, and 13 times for $\mathrm{Pb}$, which confirms the high toxic bioaccumulation potential of the studied heavy metals.

Three main groups of elements were revealed by cluster analysis: the first separated $\mathrm{Hg}$ with the highest accumulation in the Zhrebchevo Reservoir (Figure 2). The second cluster included the anthropogenic elements $\mathrm{Cu}, \mathrm{Cr}, \mathrm{Mn}, \mathrm{Ni}, \mathrm{Pb}$, and $\mathrm{Zn}$, whose highest concentrations were measured mainly in the Studen Kladenets Reservoir. Manganese was separated from the rest of the elements early (at about 15\% similarity). The third cluster grouped elements that could be interpreted as natural elements ( $\mathrm{Al}$ and $\mathrm{Fe}$ ), as well as $\mathrm{As}, \mathrm{Cd}$, and $\mathrm{Co}$, the highest concentrations of which were analyzed in moss-bags predominantly from the Kardzhali Reservoir. 


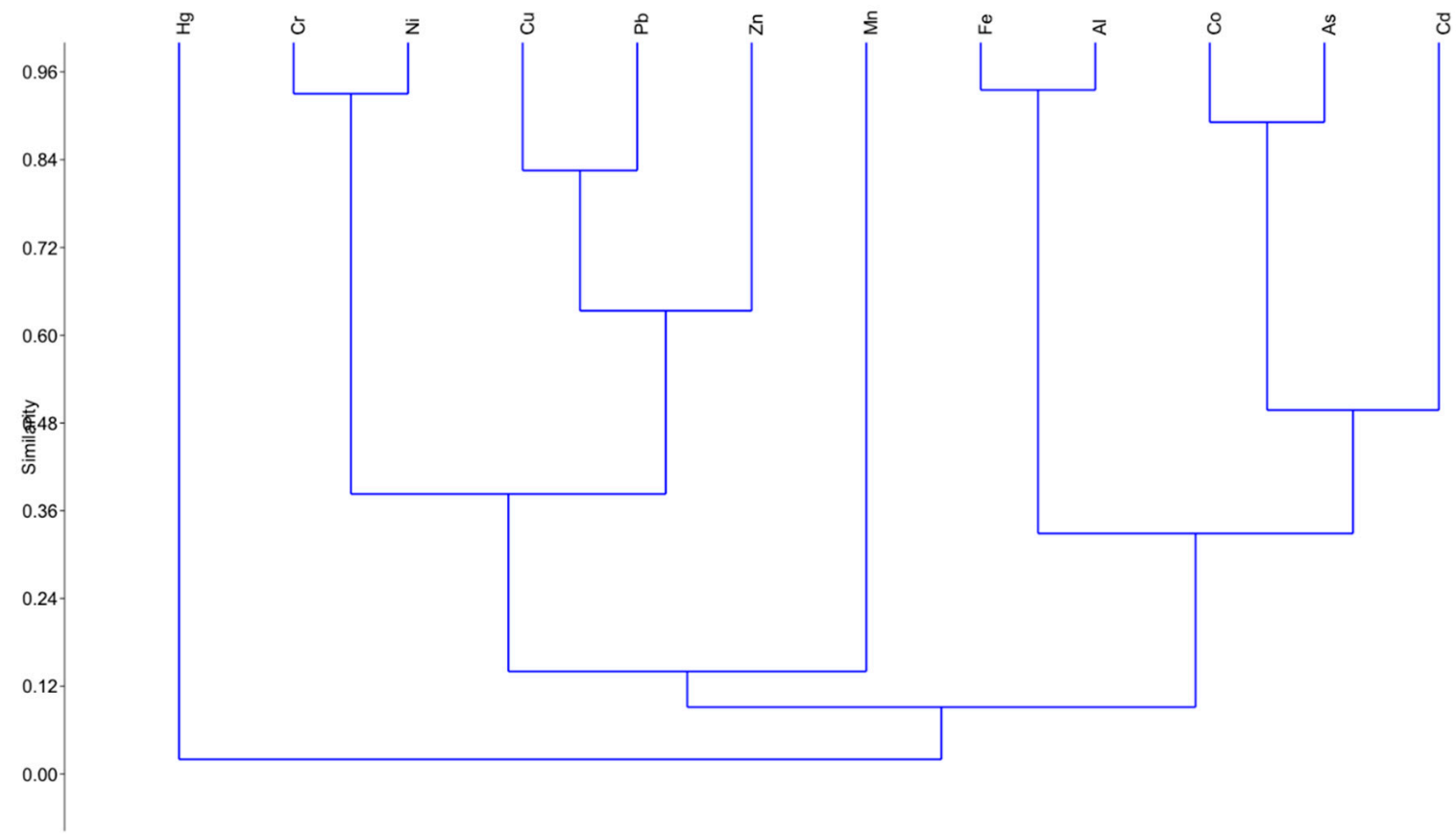

Figure 2. Cluster analysis: dendrogram of trace elements in Fontinalis antipyretica (unweighted pair-group average linkage, Bray-Curtis similarity index).

The moss-bags displayed highest overall concentrations of PBDEs (from 0.09 to $0.118 \mu \mathrm{g} \mathrm{kg}^{-1}$ ). Moreover, the SCCPs levels were alarmingly high in all plant samples (Table 1).

\subsection{Mussels}

The minimum and maximum concentrations for the studied compounds in mussels were presented in Table 1. Overall, the levels were similar between the studied stations. However, the highest values were determined for $\mathrm{Al}, \mathrm{As}, \mathrm{Co}, \mathrm{Fe}, \mathrm{Mn}$ in Zhrebchevo; $\mathrm{Cr}, \mathrm{Cu}$, Ni in Kardzhali; $\mathrm{Cd}, \mathrm{Pb}, \mathrm{Zn}$ in Studen Kladenets Reservoir. On the other hand, the lowest concentrations were measured in the mussels from the background site, except for $\mathrm{Zn}$.

The BAF calculations showed variations between the three reservoirs (Table 3). The highest values were found for $\mathrm{Cu}, \mathrm{Mn}$, and $\mathrm{Pb}$ for the mussels from $\mathrm{Zhrebchevo}$; for $\mathrm{Al}, \mathrm{Cd}, \mathrm{Co}, \mathrm{Cr}, \mathrm{P}$, and $\mathrm{Zn}$ for the mussels from Studen Kladenets, and As, M, Na, and $\mathrm{Ni}$ for the mussels from Kardzhali Reservoir. In addition, the $\mathrm{BAF}$ for $\mathrm{Al}, \mathrm{Cr}, \mathrm{Cu}, \mathrm{Ni}$, and $\mathrm{Pb}$ was extremely high for the mussels from all three studied sites, reaching thousand times more its values in the mussels compared to its corresponding levels in the water. Thus, according to the calculated BAF values, we can categorize the mussels as macroconcentrators $(>2)$. A result, which is worth mentioning is that the BAF for As and Zn differed between Kardzhali, Studen Kladenets, and Zhrebchevo reservoirs (Table 3), which is most likely due to the different type and degree of contamination. 
Table 3. Bioaccumulation factors (BAF) for 11 elements and organic contaminants in mussels from the studied stations. The analyzed elements $(\mathrm{Ca}, \mathrm{Fe}, \mathrm{Hg}, \mathrm{K})$, which were below the limit of detection (LOD) in all studied stations were excluded. Bold-highest BAF value for each element/substance.

\begin{tabular}{cccc}
\hline & Kardzhali & Studen Kladenets & Zhrebchevo \\
\hline $\mathrm{Al}$ & 343 & $\mathbf{1 0 6 4}$ & 771 \\
$\mathrm{As}$ & $\mathbf{6 6 8}$ & 122 & - \\
$\mathrm{Cd}$ & - & $\mathbf{1 1 7 6}$ & - \\
$\mathrm{Co}$ & - & $\mathbf{8 2 2}$ & - \\
$\mathrm{Cr}$ & 1232 & $\mathbf{2 3 4 5}$ & 1427 \\
$\mathrm{Cu}$ & 37,079 & 17,462 & $\mathbf{8 4 , 5 0 3}$ \\
$\mathrm{Mg}$ & $\mathbf{1 7 4}$ & 127 & 54 \\
$\mathrm{Mn}$ & 24 & 5 & $\mathbf{4 6}$ \\
$\mathrm{Na}$ & $\mathbf{1 6 2}$ & 57 & 46 \\
$\mathrm{Ni}$ & $\mathbf{9 2 8}$ & 287 & 415 \\
$\mathrm{P}$ & 28 & $\mathbf{2 9}$ & - \\
$\mathrm{Pb}$ & 2835 & 2247 & $\mathbf{6 4 0 6}$ \\
$\mathrm{Zn}$ & - & $\mathbf{1 6 2 9}$ & - \\
$\mathrm{PBDEs}$ & 0.46 & $\mathbf{0 . 5 9}$ & 0.54 \\
$\mathrm{SCCPs}$ & 0.05 & 7 & 0.47 \\
\hline
\end{tabular}

PBDEs: polybrominated diphenyl ethers.

Our results for bioaccumulation were in line with other studies on trace elements in the mussels from anthropogenic sites. We consider that such studies are essential not only for ecological monitoring but also for health risk assessment of heavy metal exposure via consumption of mussels. For example, our results for $\mathrm{Cu}$ and $\mathrm{Fe}$ concentrations in the total soft tissue of mussels corresponded to those of Yap et al. [59] (2016); however, their results for $\mathrm{Cd}, \mathrm{Pb}, \mathrm{Ni}$, and $\mathrm{Zn}$ were higher. Furthermore, Azizi et al. [60] analyzed the metal concentrations ( $\mathrm{Cd}, \mathrm{Cr}, \mathrm{Cu}, \mathrm{Fe}, \mathrm{Ni}, \mathrm{Zn}, \mathrm{Co}$, and $\mathrm{Pb}$ ) in the whole soft tissues of mussels from Cala Iris offshore (Northern Morocco) in different seasons. Unlike us, the authors did not detect $\mathrm{Co}$ and $\mathrm{Pb}$; the $\mathrm{Cu}$ concentrations were lower; the $\mathrm{Cd}$ concentrations were similar, but the $\mathrm{Cr}, \mathrm{Fe}, \mathrm{Ni}$, and $\mathrm{Zn}$ concentrations were times higher.

The applied cluster analysis divided the trace elements in S. woodiana into three groups. The first cluster, separated early at about $5 \%$ similarity, further divides into two sub-groups-one, containing only $\mathrm{Fe}$, which is a naturally occurring trace element, but along with the elements in the second sub-cluster ( $\mathrm{Zn}$ and $\mathrm{Al}, \mathrm{Cu}$ ), they also could be of anthropogenic origin, mainly due to ore extraction and mining activities. The second cluster, at only about $10 \%$ similarity contains one element- $\mathrm{Hg}$, whose toxic properties and behavior are different form all other studied contaminants, and this may explain its separation in a substantive cluster. The third cluster was also further divided into two sub-groups- the first one contained $\mathrm{As}$ and $\mathrm{Pb}$, and the second $\mathrm{Cd}, \mathrm{Ni}, \mathrm{Mn}, \mathrm{Co}$, and $\mathrm{Cr}$, which are typical contaminants, probably grouped together, based on synergetic mechanisms in their interactions in the environment (Figure 3). 


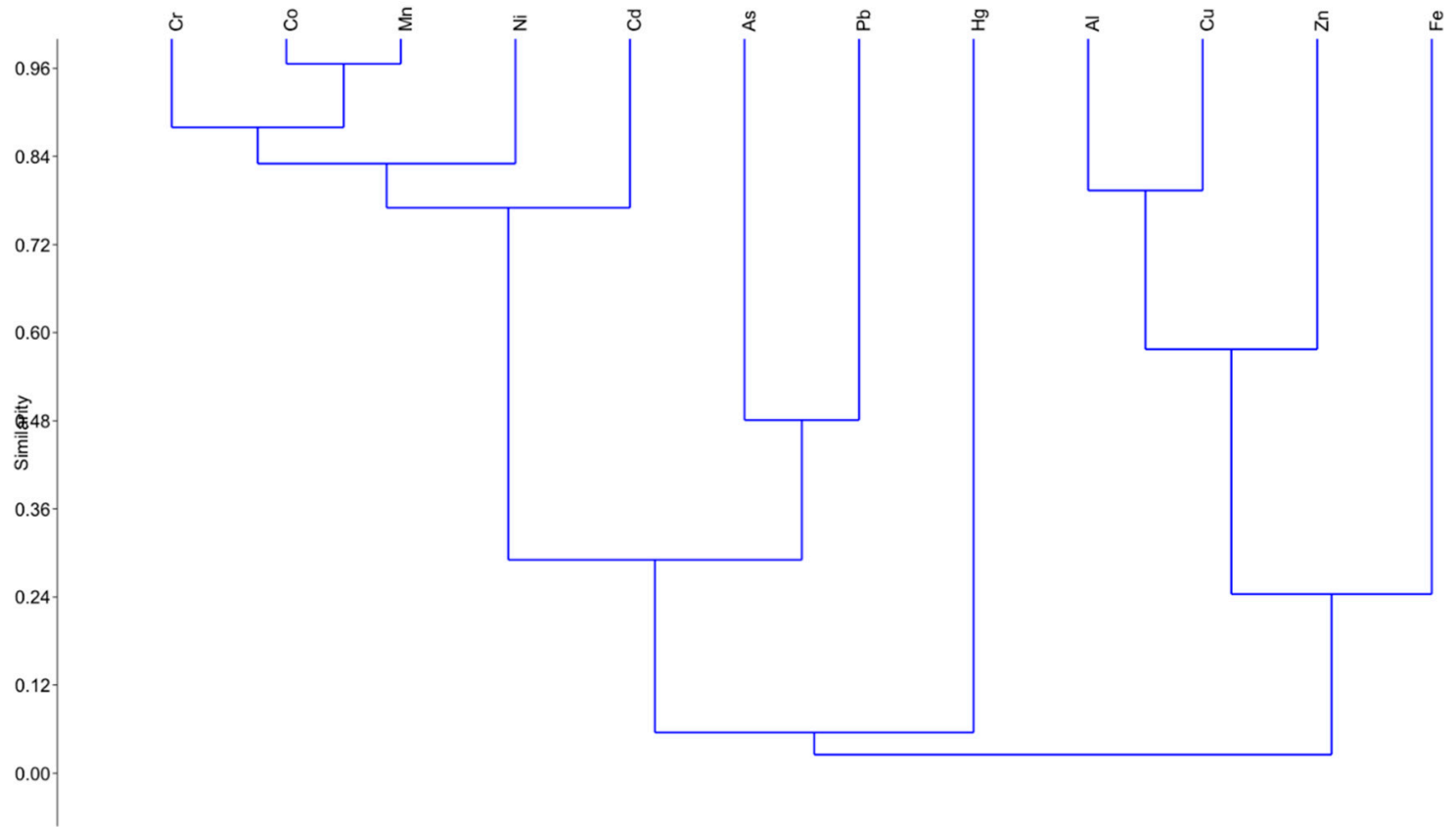

Figure 3. Cluster analysis: dendrogram of trace elements in Sinanodonta woodiana (unweighted pair-group average linkage, Bray-Curtis similarity index).

In general, the sum of PBDEs in the mussels from Kardzhali and Studen Kladenets showed a similar trend as in the water-the levels were close, 0.041 and $0.045 \mathrm{\mu g} \mathrm{kg}^{-1}$, respectively (Table 1). Furthermore, they were also higher than the measured $\sum$ PBDE concentration in the mussels from the Zhrebchevo Reservoir $\left(0.012 \mu \mathrm{g} \mathrm{kg}^{-1}\right)$. The predominant PBDE congener was BDE-47, accounting for $50 \%$ of the total PBDEs in mussels from all three reservoirs. This finding is in line with Debruyn et al. [61], who studied marine mussels (Modiolus modiolus Linnaeus, 1758) from 14 stations near a municipal outfall. A notable result, which should be pointed out, is that the SCCPs $\left(6.12 \mu \mathrm{g} \mathrm{kg}^{-1}\right)$ in the mussels from the Studen Kladenets Reservoir were 27 times higher than those measured in the Zhrebchevo Reservoir and 10 times higher than those in the Kardzhali Reservoir, respectively, which again confirmed the impact of human activity in the studied stations.

The BAF calculations for PBDEs were similar for all three reservoirs (Table 3). They were found to be between 0.46 and 0.59 , which, according to Nikanorov [53], determines the mussels as deconcentrators $(\mathrm{BAF}<1)$. However, the BAF calculations for SCCPs varied between reservoirs with highest values of 7.12 for the Studen Kladenets Reservoir. This finding describes S. woodiana as a macroconcentrator $(\mathrm{BAF}>2)$ for this organic contaminant, even though for Kardzhali and Zhrebchevo Reservoir it ranges between 0.05 and 0.47 . The calculated BAFs indicated that PBDEs have a pattern of bioaccumulative behavior in the mussels, but SCCPs may be more bioaccumulative in the mussels than PBDEs.

Our results for $S$. woodiana showed lower values for PBDEs compared to those for Mytilus edulis (Linnaeus, 1758) along the Dutch coast [62], where BAF were measured to be reaching up to 10 for some PBDEs congeners. Our BAF results (except for Studen Kladenets Reservoir) were also lower for SCCPs compared to the calculated BAF for fish and invertebrates from China by Sun et al. [63], which varied from 2.46 to 3.49. They were also lower than the BAF result for SCCPs for bivalves (1.08-1.61) in the study of Ma et al. [64]. We consider that in our case, this result also depends on the tested species.

\subsection{Integrated Transplant Monitoring}

Both bryophytes and mussels are in a close relationship with their immediate environment. The selected bryomonitor, F. antipyretica, has large biomass and high cation exchange capacity. Mussels 
as filter feeders were known to reflect levels of organic and inorganic pollutants occurring in the water, food, or sediment and thus also raise public health concerns.

Mosses contain elevated amount of $\mathrm{N}$ and $\mathrm{P}$ and other essential nutrients, and their uptake is influenced by the trace elements. A loss of $\mathrm{K}$ in the transplanted moss (between 2 and $>4$ times, Table 1), which is a very soluble nutrient, could be a result of heavy metal accumulation as suggested by Vázquez et al. [65]. The trace elements probably influenced also the content of $\mathrm{Na}$ and $\mathrm{P}$, most displaced in the Kardzhali Reservoir. The concentrations of mainly intracellular macroelements (e.g., K and P) decreased in moss tissue. In contrast, both moss and mussel tissues were enriched with $\mathrm{Ca}$ and $\mathrm{Mg}$ at the end of the exposition period in all studied stations, which confirmed the elements as mainly exchangeable ones [66]. Mussels retained similar levels of $\mathrm{K}$ and $\mathrm{Na}$ during the experiment.

Principal component analysis (PCA) logically divided the water samples from biota along the first axis. Eigenvalues of the first two axes were 0.824 and 0.136 , together explaining $95.9 \%$ of the samples-pollutants relation. The analysis indicated that in general, mosses and mussels followed a different model of trace element accumulation (Figure 4). F. antipyretica accumulated higher amounts of most of the elements (on the bottom right: $\mathrm{Al}, \mathrm{As}, \mathrm{Cd}, \mathrm{Co}, \mathrm{Cr}, \mathrm{Ni}, \mathrm{Pb}, \mathrm{Zn}$ ), while S. woodiana was associated with elevated concentrations of $\mathrm{Mn}$.

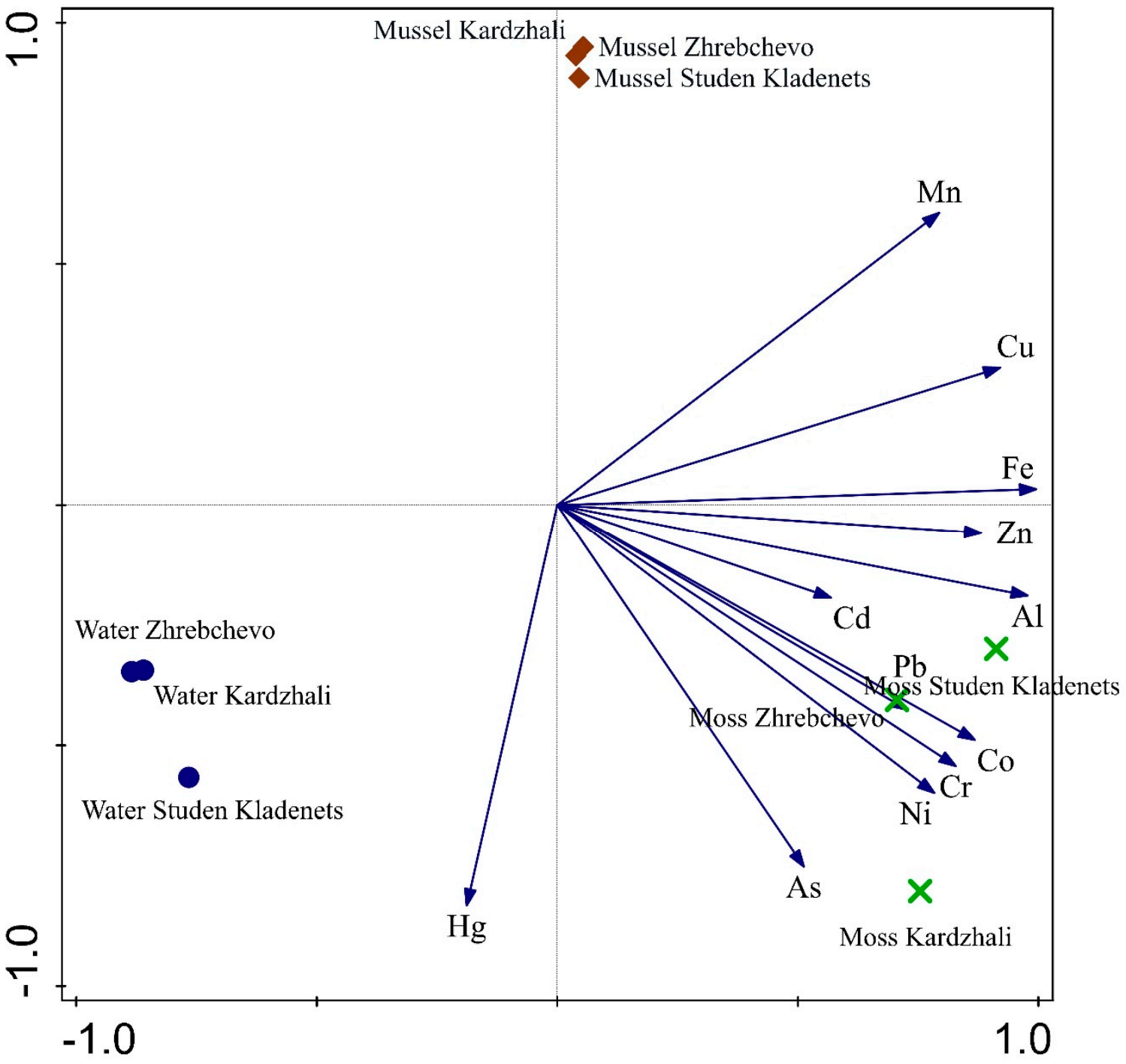

Figure 4. Principal component analysis (PCA) scatterplot of the three studied matrices: water, moss, and mussel samples. 
PBDEs in the biota exceeded the EQS ( $\sum$ PBDEs in moss from 0.09 to $0.12 \mu \mathrm{g} \mathrm{kg}{ }^{-1}$; mussel 0.01-0.05 $\left.\mu \mathrm{g} \mathrm{kg}^{-1}\right)$. There was a predominance of BDE-99, 100, and 153 in the moss tissues, whereas BDE-47 dominated in the mussels. BDE- 47 dominated both in terrestrial mosses and herbivores in Norway [67], and its dominance in mussels probably reflects different bioaccumulation properties or metabolic transformation processes of the BDE- 47 in aquatic environment. BDE- 47 was again the most frequently found in Swedish terrestrial mosses with concentrations between $<0.06$ and $0.46 \mathrm{ng} / \mathrm{g}$ DW, while BDE 28, 47, 99, 100, 153, 154 were generally low or below the quantification limit for the analysis [68].

The levels of PBDEs in the moss showed similar pollution in the three reservoirs, while the mussels assessed Kardzhali and Studen Kladenets as more contaminated. There were no statistically significant linear correlations between the PBDEs in the water and in the biota.

As for the SCCPs, the moss samples accumulated high levels, which correlated to those in the water. Short-chain chlorinated paraffins in mussels have a highest calculated BAF of 7.12, thus, this compound could be considered to be bioaccumulative.

\section{Conclusions}

The active monitoring applied here, which combines moss and mussel data, seems adequate to study the persistent impact of industrial and untreated waste pollution on aquatic environment. The transplants with Fontinalis antipyretica and Sinanodonta woodiana in this study revealed severe contamination with heavy metals in two of the reservoirs related to former industrial impact, which on the other hand was not detected by water samples. Another general finding was that PBDEs and SCCPs were found in all biotic samples and were confirmed as bioaccumulative compounds.

Although inorganic and organic pollutants accumulated by the moss were higher than those in the mussels, both monitors are complementary. Mosses and mussels followed a different model of trace element accumulation. In addition, the domination of BDE-99, 100, and 153 in the moss and BDE- 47 in the mussels reflects different bioaccumulation properties. Thus, integrated monitoring with moss-bags and transplanted mussels should be applied in reservoirs, especially those used for aquaculture, in order to control the water status, to observe pollution trends, and to prevent a potential hazard to human health.

Still, many questions persist: how many monitoring sites are necessary and where to place them. Furthermore, in this pilot study we assume that the uptake of the contaminants is rapid when concentrations are high, but the influence of the negligible water flow velocity in reservoirs has to be studied further. We believe that in the future, such monitoring will be increasingly used to find the answer to the above questions and allow assessment of different pollutants in standing water bodies.

Author Contributions: Conceptualization, G.G. and V.Y.; methodology and investigation, G.G., S.S., D.A., V.S., D.G., V.G., and B.T.; software, I.M. and G.G.; data curation, I.M., G.G., and V.Y.; writing-original draft preparation, G.G. and V.Y.; writing-review and editing, I.M., V.S., I.V., and E.G.; visualization, G.G., V.Y., and I.M.; supervision, G.G.; project administration, G.G. and I.M.; funding acquisition, G.G. All authors have read and agreed to the published version of the manuscript.

Funding: This work was supported by the NPD—Plovdiv University "Paisii Hilendarski" under grant no. FP19-BF-013, "Live water, air, and health with transplants-LIFE".

Acknowledgments: The article is dedicated to the memory of Lilyana Yurukova, one of the first researchers who introduced the moss-bag technique. We would like to thank the assistant editor Nicole Ma and two anonymous reviewers for their contributions to this manuscript.

Conflicts of Interest: The authors declare no conflict of interest.

\section{References}

1. Núñez, R.; García, M.Á.; Alonso, J.; Melgar, M.J. Arsenic, cadmium and lead in fresh and processed tuna marketed in Galicia (NW Spain): Risk assessment of dietary exposure. Sci. Total Environ. 2018, 627, 322-331. [CrossRef] 
2. Ali, H.; Khan, E.; Ilahi, I. Environmental chemistry and ecotoxicology of hazardous heavy metals: Environmental persistence, toxicity, and bioaccumulation. J. Chem. 2019, 2019, 14. [CrossRef]

3. Wania, F.; Dugani, C.B. Assessing the long-range transport potential of polybrominated diphenyl ethers: A comparison of four multimedia models. Environ. Toxicol. Chem. 2003, 22, 1252-1261. [CrossRef]

4. Ondarza, P.M.; Gonzalez, M.; Fillmann, G.; Miglioranza, K.S.B. PBDEs, PCBs and organochlorine pesticides distribution in edible fish from Negro River basin, Argentinean Patagonia. Chemosphere 2014, 94, 135-142. [CrossRef]

5. De Wit, C.A. An overview of brominated flame retardants in the environment. Chemosphere 2002, 46, 583-624. [CrossRef]

6. De Wit, C.A.; Herzke, D.; Vorkamp, K. Brominated flame retardants in the Arctic environment-Trends and new candidates. Sci. Total Environ. 2010, 408, 2885-2918. [CrossRef]

7. Zeng, L.; Lam, J.C.W.; Chen, H.; Du, B.; Leung, K.M.Y.; Lam, P.K.S. Tracking dietary sources of short- and medium-chain chlorinated paraffins in marine mammals through a subtropical marine food web. Environ. Sci. Technol. 2017, 51, 9543-9552. [CrossRef]

8. Gong, Y.; Zhang, H.; Geng, N.; Ren, X.; Giesy, J.P.; Luo, Y.; Xing, L.; Wu, P.; Yu, Z.; Chen, J. Short-chain chlorinated paraffins (SCCPs) disrupt hepatic fatty acid metabolism in liver of male rat via interacting with peroxisome proliferatoractivated receptor $\alpha(\operatorname{PPAR} \alpha)$. Ecotoxicol. Environ. Saf. 2019, 181, 164-171. [CrossRef]

9. Bayen, S.; Obbard, J.P.; Thomas, G.O. Chlorinated paraffins: A review of analysis and environmental occurrence. Environ. Int. 2006, 32, 915-929. [CrossRef]

10. Wang, P.; Zhao, N.; Cui, Y.; Jiang, W.; Lina, W.; Zhenhua, W.; Chen, X.; Jiang, L.; Ding, L. Short-chain chlorinated paraffin (SCCP) pollution from a CP production plant in China: Dispersion, congener patterns and health risk assessment. Chemosphere 2018, 211, 456-464. [CrossRef]

11. Law, R.J.; Covaci, A.; Harrad, S.; Herzke, D.; Abdallah, M.A.; Fernie, K.; Toms, L.M.; Takigami, H. Levels and trends of PBDEs and HBCDs in the global environment: Status at the end of 2012. Environ. Int. 2014, 65, 147-158. [CrossRef]

12. Houde, M.; Muir, D.C.; Tomy, G.T.; Whittle, D.M.; Teixeira, C.; Moore, S. Bioaccumulation and trophic magnification of short- and medium-chain chlorinated paraffins in food webs from Lake Ontario and Lake Michigan. Environ. Sci. Technol. 2008, 42, 3893-3899. [CrossRef] [PubMed]

13. Huang, H.; Gao, L.; Xia, D.; Qiao, L. Bioaccumulation and biomagnification of short and medium chain polychlorinated paraffins in different species of fish from Liaodong Bay, North China. Sci. Rep. 2017, 7, 10749. [CrossRef] [PubMed]

14. Shi, J.; Li, X.; He, T.; Wang, J.; Zhen, W.; Li, P.; Yongzhong, L.; Sanganyado, E.; Liu, W. Integrated assessment of heavy metal pollution using transplanted mussels in eastern Guangdong, China. Environ. Pollut. 2018, 243, 601-609. [CrossRef] [PubMed]

15. Schulze, S.; Zahn, D.; Montes, R.; Rodil, R.; Quintana, J.B.; Knepper, T.P.; Reemtsma, T.; Berger, U. Occurrence of emerging persistent and mobile organic contaminants in European water samples. Water Res. 2019, 153, 80-90. [CrossRef]

16. Kesavan, K.; Murugan, A.; Venkatesan, V.; Vijay Kumar, B.S. Heavy metal accumulation in molluscs and sediment from uppanar estuary, southeast coast of India. Thalassas 2013, 29, 15-21.

17. Kumar, V.; Sinha, A.K.; Rodrigues, P.P.; Mubiana, V.K.; Blust, R.; De Boeck, G. Linking environmental heavy metal concentrations and salinity gradients with metal accumulation and their effects: A case study in 3 mussel species of Vitoria estuary and Espírito Santo bay, Southeast Brazil. Sci. Total Environ. 2015, 523, 1-15. [CrossRef]

18. Azizi, G.; Akodad, M.; Baghour, M.; Layachi, M.; Moumen, A. The use of Mytilus spp. mussels as bioindicators of heavy metal pollution in the coastal environment. A review. JMES 2018, 9, 1170-1181.

19. Debén, S.; Fernández, J.A.; Carballeira, A.; Aboal, J.R. Using devitalized moss for active biomonitoring of water pollution. Environ. Pollut. 2016, 210, 315-322. [CrossRef]

20. Benson-Evans, K.; Williams, P.F. Transplanting aquatic bryophytes to assess river pollution. J. Bryol. 1976, 9 , 81-91. [CrossRef]

21. Figueira, R.; Ribeiro, T. Transplants of aquatic mosses as biomonitors of metals released by a mine effluent. Environ. Pollut. 2005, 136, 293-301. [CrossRef] 
22. Samecka-Cymerman, A.; Kolon, K.; Kempers, A.J. A comparison of native and transplanted Fontinalis antipyretica Hedw. as biomonitor of water polluted with heavy metals. Sci. Total Environ. 2005, 341, 97-107. [CrossRef]

23. Gecheva, G.; Yurukova, L. Water pollutant monitoring with aquatic bryophytes: A review. Environ. Chem. Lett. 2014, 12, 49-61. [CrossRef]

24. Kucuksezgin, F.; Pazi, I.; Yucel-Gier, G.; Akcali, B.; Galgani, F. Monitoring of heavy metal and organic compound levels along the Eastern Aegean coast with transplanted mussels. Chemosphere 2013, 93, 1511-1518. [CrossRef]

25. Goldberg, E.D. The Mussel Watch-a first step in global marine monitoring. Mar. Pollut. Bull. 1975, 6, 111-114. [CrossRef]

26. Goldberg, E.D. The Mussel Watch concept. Environ. Monit. Assess. 1986, 7, 91-103. [CrossRef]

27. Martin, M. State Mussel Watch: Toxics surveillance in California. Mar. Pollut. Bull. 1985, 16, 140-146. [CrossRef]

28. Lauenstein, G.G.; Robertson, A.; O'Connor, T.P. Comparison of trace metal data in mussels and oysters from a mussel watch programme of the 1970s with those from a 1980s programme. Mar. Pollut. Bull. 1990, 21, 440-447. [CrossRef]

29. Sparks, C.; Odendaal, J.; Snyman, R. An analysis of historical Mussel Watch Programme data from the west coast of the Cape Peninsula, Cape Town. Mar. Pollut. Bull. 2014, 87, 374-380. [CrossRef]

30. Farrington, J.W.; Tripp, B.W.; Tanabe, S.; Subramanian, A.; Sericano, J.L.; Wade, T.L.; Knap, A.H.; Edward, D. Goldberg's proposal of "the mussel watch": Reflections after 40 years. Mar. Pollut. Bull. 2016, 110, 501-510. [CrossRef]

31. Robinson, C.D.; Webster, L.; Martínez-Gomez, C.; Burgeot, T.; Gubbins, M.J.; Thain, J.E.; Vethaak, A.D.; Mcintosh, A.D.; Hylland, K. Assessment of contaminant concentrations in sediments, fish and mussels sampled from the North Atlantic and European regional seas within the ICON project. Mar. Environ. Res. 2017, 124, 21-31. [CrossRef] [PubMed]

32. Watters, G.T. Synthesis and review of the expanding range of the Asian freshwater mussel Anodonta woodiana (Lea, 1834) (Bivalvia: Unionidae). Veliger 1997, 40, 152-156.

33. Popa, O.P.; Bartakova, V.; Bryja, J.; Reichard, M.; Popa, L.O. Characterization of nine microsatellite markers and development of multiplex PCRs for the Chinese huge mussel Anodonta (Sinanodonta) woodiana Lea, 1834 (Mollusca, Bivalvia). Biochem. Syst. Ecol. 2015, 60, 234-237. [CrossRef]

34. Soroka, M.; Urbanska, M.; Andrzejewski, W. Chinese pond mussel Sinanodonta woodiana (Lea, 1834) (Bivalvia): Origin of the Polish population and GenBank data. J. Limnol. 2014, 73, 454-458. [CrossRef]

35. Lopes-Lima, M.; Sousa, R.; Geist, J.; Aldridge, D.C.; Araujo, R.; Bergengren, J.; Bespalaja, Y.; Bódis, E.; Burlakova, L.; Van Damme, D.; et al. Conservation status of freshwater mussels in Europe: State of the art and future challenges. Biol. Rev. Camb. Philos. Soc. 2016, 92, 572-607. [CrossRef]

36. Kolarević, S.; Knežević-Vukčević, J.; Paunović, M.; Kračun, M. Monitoring of DNA damage in haemocytes of freshwater mussel Sinanodonta woodiana sampled from the Velika Morava River in Serbia with the comet assay. Chemosphere 2013, 93, 243-251. [CrossRef]

37. Liu, H.; Yang, J.; Gan, J. Trace element accumulation in bivalve mussels Anodonta woodiana from Taihu Lake, China. Arch. Environ. Contam. Toxicol. 2010, 59, 593-601. [CrossRef]

38. Uno, S.; Shiraishi,H.; Hatakeyama, S.; Otsuki, A.; Koyama, J. Accumulative characteristics of pesticide residues in organs of bivalves (Anodonta woodiana and Corbicula leana) under natural conditions. Arch. Environ. Contam. Toxicol. 2001, 40, 35-47.

39. Woznicki, P.; Lewandowska, R.; Brzuzan, P.; Ziomek, E.; Bardega, R. The level of DNA damage and the frequency of micronuclei in haemolymph of freshwater mussels (Anadonta woodiana) exposed to benzo[a]pyrene. Acta Toxicol. 2004, 12, 41-45.

40. Yancheva, V.; Mollov, I.; Velcheva, I.; Georgieva, E.; Stoyanova, S. Effects of cadmium (Cd) on the lysosomal membrane stability and respiration rate of two freshwater mollusks under ex situ exposure: Preliminary data. South West J. Hortic. Biol. Environ. 2016, 7, 27-34.

41. Yancheva, V.; Mollov, I.; Velcheva, I.; Georgieva, E.; Stoyanova, S. Heavy metal effects on the lysosomal membrane stability and respiratory rate in Chinese Pond Mussel (Sinanodonta woodiana) under ex situ exposure: Preliminary data. Biharean Biol. 2016, 10, 55-57. 
42. Chen, X.B.; Liu, H.B.; Su, Y.P.; Yang, J. Morphological development and growth of the freshwater mussel Anodonta woodiana from early juvenile to adult. Invertebr. Reprod. Dev. 2015, 59, 131-140. [CrossRef]

43. Cenci, R.M. The use of aquatic moss (Fontinalis antipyretica) as monitor of contamination in standing and running waters: Limits and advantages. J. Limnol. 2000, 60, 53-61. [CrossRef]

44. Mersch, J.; Johansson, L. Transplanted aquatic mosses and freshwater mussels to investigate the trace metal contamination in the rivers Meurthe and Plaine, France. Environ. Technol. 1993, 14, 1027-1036. [CrossRef] [PubMed]

45. Gasmi, S.; Bernard, I.; Pouvreau, S.; Maurer, D.; Schaal, G.; Ganthy, F.; Cominassi, L.; Allain, G.; Sautour, B.; David, V. Spatial patterns in the condition index of the wild Pacific oyster Crassostrea gigas in a macrotidal coastal ecosystem: Influence of tidal processes and beyond. J. Sea Res. 2017, 119, 28-36. [CrossRef]

46. Rosseland, B.O.; Massabuau, J.C.; Grimalt, J.; Hofer, R.; Lackner, R.; Raddum, G.; Rognerud, S.; Vives, I. Fish Ecotoxicology: European Mountain Lake Ecosystems Regionalisation, Diagnostic and Socio-Economic Evaluation -Fish Sampling Manual for Live Fish; Norwegian Institute for Water Research: Oslo, Norway, 2003.

47. Velcheva, I. Zinc content in the organs and tissues of freshwater fish from the Kardjali and Studen Kladenets Dam Lakes in Bulgaria. Turk. J. Zool. 2006, 30, 1-7.

48. Gribacheva, N.; Gecheva, G.; Stefanova, V. Air pollution monitoring with mosses in Western Rhodopes, Bulgaria. Bulg. Chem. Commun. 2019, 51, 256-260. [CrossRef]

49. Mouvet, C. Rapport de contrat à l'Agence de l'Eau Rhin-Meuse et l'Agence de l'Eau Rhône-Méditerranée-Corse. In Métaux Lourds Et Mousses Aquatiques, Synthèse Méthodologique; Université de Metz Laboratoire d'Ecologie: Metz, France, 1986; p. 104.

50. Gonçalves, E.P.R.; Boaventura, R.A.R.; Mouvet, C. Sediments and aquatic mosses as pollution indicators for heavy metals in the Ave river basin (Portugal). Sci. Total Environ. 1992, 114, 7-24. [CrossRef]

51. Soares, H.M.V.M.; Boaventura, R.A.R.; Machado, A.A.S.C.; Esteves da Silva, J.C.G. Sediments as monitors of heavy metal contamination in the Ave river basin (Portugal): Multivariate analysis of data. Environ. Pollut. 1999, 105, 311-323. [CrossRef]

52. European Union. Directive 2000/60/EC of the European Parliament and of the Council of 23 October 2000 establishing a framework for community action in the field of water policy. Off. J. Eur. Communities 2000, $327,1-72$.

53. Nikanorov, A.; Julidkov, A.; Pokarzevskii, A. Biomonitoping of Heavy Metals in Freshwater Ecosystems; Hydrometeoizdat: Leningrad, Russia, 1985; p. 144. (In Russian)

54. Hammer, O.; Harper, D.; Ryan, P. PAST: PA leontological ST atistical software package for education and data analysis. Paleontol. Electron. 2001, 4, 9.

55. Smilauer, P.; Budejovice, C. CANOCO 5, Ecological Multivariate Data Ordination Program; Biometris Wageninen-UR: Wageningen, The Netherlands, 2014.

56. Samecka-Cymerman, A.; Kolon, K.; Kempers, A.J. Heavy metals in aquatic bryophytes from the Ore Mountains (Germany). Ecotoxicol. Environ. Saf. 2002, 52, 203-210. [CrossRef]

57. Basile, A.; Sorbo, S.; Pisani, T.; Paoli, L.; Munzi, S.; Loppi, S. Bioacumulation and ultrastructural effects of $\mathrm{Cd}, \mathrm{Cu}, \mathrm{Pb}$ and $\mathrm{Zn}$ in the moss Scorpiurum circinatum (Brid.) Fleisch \& Loeske. Environ. Pollut. 2012, 166, 208-211. [PubMed]

58. Camizuli, E.; Monna, F.; Scheifler, R.; Amiotte-Suchet, P.; Losno, R.; Beis, P.; Bohard, B.; Chateau, C.; Alibert, P. Impact of trace metals from past mining on the aquatic ecosystem: A multi-proxy approach in the Morvan (France). Environ. Res. 2014, 134, 410-419. [CrossRef] [PubMed]

59. Yap, C.K.; Cheng, W.H.; Karami, A.; Ismail, A. Health risk assessments of heavy metal exposure via consumption of marine mussels collected from anthropogenic sites. Sci. Total Environ. 2016, 553, 285-296. [CrossRef] [PubMed]

60. Azizi, G.; Layachi, M.; Akodad, M.; Yáñez-Ruiz, D.R.; Martín-García, A.I.; Baghour, M.; Mesfioui, A.; Skalli, A.; Moumen, A. Seasonal variations of heavy metals content in mussels (Mytilus galloprovincialis) from Cala Iris offshore (Northern Morocco). Mar. Pollut. Bull. 2018, 137, 688-694. [CrossRef]

61. Debruyn, A.M.; Meloche, L.M.; Lowe, C.J. Patterns of bioaccumulation of polybrominated diphenyl ether and polychlorinated biphenyl congeners in marine mussels. Environ. Sci. Technol. 2009, 43, 3700-3704. [CrossRef] 
62. Booij, K.; Zegers, B.N.; Boon, J.P. Levels of some polybrominated diphenyl ether (PBDE) flame retardants along the Dutch coast as derived from their accumulation in SPMDs and blue mussels (Mytilus edulis). Chemosphere 2002, 46, 683-688. [CrossRef]

63. Sun, R.; Luo, X.; Tang, B.; Chen, L.; Liu, Y.; Maia, B. Bioaccumulation of short chain chlorinated paraffins in a typical freshwater food web contaminated by e-waste in south china: Bioaccumulation factors, tissue distribution, and trophic transfer. Environ. Pollut. 2017, 222, 165-174. [CrossRef]

64. Ma, X.; Chen, C.; Zhang, H.; Gao, Y.; Wang, Z.; Yao, Z.; Chen, J.; Chen, J. Congener-specific distribution and bioaccumulation of short-chain chlorinated paraffins in sediments and bivalves of the Bohai Sea, China. Mar. Pollut. Bull. 2014, 79, 299-304. [CrossRef]

65. Vázquez, M.D.; López, J.; Carballeira, A. Uptake of heavy metals to the extracellular and intracellular compartments in three species of aquatic bryophyte. Ecotoxicol. Environ. Saf. 1999, 44, 12-24. [CrossRef] [PubMed]

66. García-Álvaro, M.A.; Martínez-Abaigar, J.; Núñez-Olivera, E.; Beaucourt, N. Element concentrations and enrichment ratios in the aquatic moss Rhynchostegium riparioides along the River Iregua (La Riojia, Northern Spain). Bryologist 2000, 103, 518-533. [CrossRef]

67. Mariussen, E.; Steinnes, E.; Breivik, K.; Nygård, T.; Schlabach, M.; Kålås, J.A. Spatial patterns of polybrominated diphenyl ethers (PBDEs) in mosses, herbivores and a carnivore from the Norwegian terrestrial biota. Sci. Total Environ. 2008, 404, 162-170. [CrossRef] [PubMed]

68. Danielsson, H.; Hansson, K.; Potter, A.; Friedrichsen, J.; Brorström-Lundén, E. Persistant Organic Pollutants in Swedish Mosses; Swedish Environmental Research Institute: Stockholm, Sweden, 2016; p. 34.

(C) 2020 by the authors. Licensee MDPI, Basel, Switzerland. This article is an open access article distributed under the terms and conditions of the Creative Commons Attribution (CC BY) license (http://creativecommons.org/licenses/by/4.0/). 